\title{
Analysis of Small ruminant market system in different agro-climatic zones of Southern India
}

\author{
D Ramesh, H R Meena and K L Meena \\ Division of Extension Education \\ Indian Veterinary Research Institute, Izatnagar-243122, Bareilly- U.P. India \\ *Corresponding author Email: drhrmeena@yahoo.co.in \\ Received: 16-11-2011, Accepted: 23-12-2011, Published Online: 24-01-2011 \\ doi: 10.5455/vetworld.2012.288-293
}

\begin{abstract}
This study examines the marketing system of small ruminants in three different agro-climatic zones of Karnataka in India. Multistage random sampling technique was used to select 60 small ruminant farmers from three viz. Bijapur (Arid zone), Gulbarga (Semi-arid zone) and Udupi (Coastal zone) district of Karnataka state. A structured questionnaire which had earlier been subject to face validity and has a reliability coefficient of 0.87 was used to collect data from the samples respondents. Data was analysed using statistical package for social science (SPSS).The results of the study revealed that marketing of small ruminants is haphazard in the study areas. Majority of the respondents $(85 \%)$ sold their animal when they needed cash for home consumption followed by to pay off loan $(28.3 \%)$ was the main reason to sell their animals. Important marketing channels were relatives and friends, local markets and village collectors. Farmers gave different reasons for selling their animals through different channels. Majority of the farmers used relatives and friends as one of the marketing channels. Most of farmers also felt that there was a difference in the price offered by village collectors and the price they were getting in the livestock markets. And a few of them were of the opinion that village collectors were not reliable in marketing. Price of the animals was establishing based on the body confirmation of the animal. Study also revealed that injured animals fetch less value than the healthy animals.
\end{abstract}

Key words: Agro-climatic Zone, Goat, Marketing of Small Ruminant, Sheep, Small Ruminant

To cite this article :

Ramesh D, Meena HR and Meena KL (2012) Analysis of Small ruminant market system in different agro-climatic zones of Southern India, Vet. World. 5(5):288-293, doi: 10.5455/vetworld.2012.288-293

\section{Introduction}

Small ruminants (i.e. sheep and goats) make a very valuable contribution to the poor in the rural areas. Their importance is indicating by various functional contributions (meat, milk, fibre, skin etc), socio-economic relevance and stability to farming systems (Rangnekar 2006). Small ruminants contribute enormously towards promotion of livelihood security and as an insurance cover to cope with crop failures particularly for rural landless, small and marginal male /female farmers (Pasha 2000, Misra 2005). Goat farming is also increasingly being taken up by periurban poor population due to easy market access and as a source of nutritional security for the household (Pollot and Wilson 2009). The profitability of small ruminant farming depends upon the effective marketing of the products. But, in India, marketing of sheep and goats is unorganized and involves various middlemen, unnecessary transportation and death of animals during transportation. Lack of awareness of markets, pricing structure, unorganized marketing facilities coupled with distress sale are the major reasons for not receiving fair price for their animals by the farmers (BAIF 2008, Porwal et al 2006).

Keeping in view the above, the present study was conducted to provide a better understanding of marketing systems for small ruminants in different agro-climatic zones of Karnataka state of India.

\section{Materials and Methods}

The study was conducted in Karnataka state of India. Three districts selected in such a way that each district represented an agro-climatic zone. Selected districts were Bijapur (represented arid zone), Gulbarga (represented semi-arid zone) and Udupi (represented coastal zone). Multistage sampling procedure was used to select sixty small ruminant farmers. Twenty farmers were selected from each district. The data were obtained from the farmers by the investigator with the help of a structured interview schedule. The data were scrutinized, collated and analyzed using SPSS-11.0 software. 
Analysis of Small ruminant market system in different agro-climatic zones of Southern India

Table-1. Socio-economic characteristics of small ruminant farmers

\begin{tabular}{|c|c|c|c|c|}
\hline Parameters & Semi-arid Zone $(n=20)$ & Arid Zone $(n=20)$ & Coastal Zone $(n=20)$ & Pooled $(\mathrm{N}=60)$ \\
\hline \multicolumn{5}{|l|}{ Family Type } \\
\hline Nuclear & 70 & 70 & 85 & 75 \\
\hline Joint & 30 & 30 & 15 & 25 \\
\hline \multicolumn{5}{|l|}{ Family Size } \\
\hline Small (3-7 members) & 75 & 40 & 85 & 76.6 \\
\hline Medium (8-12 members) & 15 & 25 & 10 & 16.6 \\
\hline Large (13-15 members) & 10 & 5 & 5 & 46.6 \\
\hline Primary & 20 & 10 & 15 & 15 \\
\hline Middle & 5 & 10 & 20 & 11.6 \\
\hline High school & 10 & 20 & 15 & 15 \\
\hline Pre- university & 15 & 15 & 20 & 16.6 \\
\hline Graduation & 5 & 5 & 20 & 10 \\
\hline \multicolumn{5}{|l|}{ Land holding (in acres) } \\
\hline Landless (nil) & 5 & 15 & 20 & 13.3 \\
\hline Low $(2-11)$ & 45 & 50 & 60 & 53.3 \\
\hline Medium (12-21) & 40 & 25 & 25 & 31.6 \\
\hline High (22-31) & 15 & 25 & 5 & 15 \\
\hline \multicolumn{5}{|l|}{ Flock size } \\
\hline Small (2-9 animals) & 60 & 40 & 65 & 55 \\
\hline Medium (10-17 animals) & 20 & 40 & 35 & 31.6 \\
\hline Large (18-25 animals) & 20 & 20 & 0 & 13.3 \\
\hline \multicolumn{5}{|l|}{ Total annual income } \\
\hline Low $(12,000-24,666)$ & 35 & 25 & 40 & 33 \\
\hline Medium $(24,667-37,332)$ & 45 & 70 & 50 & 55 \\
\hline High $(37,333-50,000)$ & 20 & 5 & 10 & 11.6 \\
\hline \multicolumn{5}{|c|}{ Annual income from small ruminants } \\
\hline Low $(1300-5866)$ & 45 & 40 & 55 & 46.6 \\
\hline Medium (5867-10432) & 25 & 30 & 35 & 30 \\
\hline
\end{tabular}

\section{Results and Discussion}

The results in Table-1 indicated that majority of the respondents were nuclear family type (75\%), about 76.6\% were having 3-7 family member, while $31.6 \%$ of respondents were illiterate and about $45 \%$ respondents were marginal farmers who had less than 2.5 acres of land. Majority of the farmers $53.3 \%$ having low level of experience in small ruminant farming while majority $55 \%$ of responders having small size of flock (2-9 animals). In case of total annual income $55 \%$ of farmers belong to medium income group (INR 24,667-37,332) whereas, income concerned from small ruminants only $46.6 \%$ farmers earned INR 1300-5866 annually and belong to low level of income group.

Reasons to sell: The only readily available asset for marginal and landless farmers for selling animals to meet any immediate household expenditure was sheep and goats. Farmers were asked to offer reasons for sale of their animals. Table- 2 points out that majority of the respondents $(85 \%)$ sold their animals when they needed cash for home consumption followed by to pay off loan $(28.4 \%)$. A few respondents $(25 \%)$ sold their animals to pay their children's school fees. Surplus animals have also forced few farmers $(11.6 \%)$ to sell their animals because of difficulty in management. Pankaj and Singh (2008) found that the main reason for selling goats in India was urgent need of money. The similar findings also reported by Gemeda at al 2005, that the major reasons of sheep and goat sold include: school expenses for children, purchase of farm inputs (fertilizer, seed, farm items) and purchase of food, expenses for health and to pay back credit $46.1 \%, 37.5 \%, 31.3 \%, 28.1 \%$, respectively. Farmers sell their small ruminants as savings at time of crop failure or drought (Workneh et al 2003, Tsedeke 2007 and Getahun 2008). Small ruminants are also sold for cash generation purpose (Endashew 2007, Tsedeke 2007), where uncertainly of rainfall is observed, women and children are involved in owning and keeping small ruminants for immediate income generation (Abule 1998) reported in their respective study area.

Table 2 also shows that in all the three agro climatic zone need of cash for home consumption was the main reason to sell the animals, followed by paying children's school fees and repaying loan. In semi-arid 
Table-2. Small ruminants sale pattern and marketing channels

\begin{tabular}{|c|c|c|c|c|}
\hline Reasons for Sell & emi-arid Zone $(n=20)$ & Arid Zone $(n=20)$ & Coastal Zone $(n=20)$ & Pooled $(\mathrm{N}=60)$ \\
\hline Need money to pay children' school fees & 35 & 15 & 25 & 25 \\
\hline To repay a loan & 30 & 35 & 20 & 28.4 \\
\hline \multicolumn{5}{|l|}{ Channels used } \\
\hline Village collectors & 55 & 75 & 65 & 65 \\
\hline Local Market & 50 & 60 & 40 & 50 \\
\hline Village collectors & $(\mathrm{N}=11)$ & $(\mathrm{N}=15)$ & $(\mathrm{N}=13)$ & $(\mathrm{N}=39)$ \\
\hline Easy and fast & 81.8 & 60 & 100 & 79.4 \\
\hline Availability of credit & 27.2 & 6.6 & 0 & 10.2 \\
\hline Collection from house & 63.6 & 53.3 & 46.1 & 53.8 \\
\hline Advance payment & 36.3 & 20 & 15.3 & 27 \\
\hline Local Market & $(N=10)$ & $(\mathrm{N}=12)$ & $(\mathrm{N}=8)$ & $(\mathrm{N}=30)$ \\
\hline Remunerative price & 70 & 100 & 62.5 & 80 \\
\hline Availability of credit & 16.6 & 5.2 & 0 & 7.4 \\
\hline Collection from house & 11 & 21 & 17.6 & 16.6 \\
\hline Advance payment & 44.4 & 42.1 & 11.7 & 33.3 \\
\hline Personal dealing & 27.7 & 21 & 5.8 & 18.5 \\
\hline Market plan & $(n=20)$ & $(n=20)$ & $(n=20)$ & $(\mathrm{N}=60)$ \\
\hline Have & 45 & 40 & 55 & 46.6 \\
\hline Don't have & 55 & 60 & 45 & 53.3 \\
\hline Price estimation by & $(\mathrm{N}=20)$ & $(\mathrm{N}=20)$ & $(\mathrm{N}=20)$ & $(\mathrm{N}=60)$ \\
\hline Judaing by the body confirmation & 45 & 35 & 55 & 46.6 \\
\hline Market Demand & 15 & 20 & 10 & 15 \\
\hline Both & 40 & 45 & 35 & 38.3 \\
\hline
\end{tabular}

and coastal zone 10 percent respondents sold because of surplus animals. However, in arid zone repaying loan was second priority followed by paying children's school fees and surplus number. Though majority of the sheep and goats sold were male animals, farmers were retaining female stock to develop the flock.

Marketing Channels used: A perusal of table 2 indicates that about 90 per cent of respondents used relatives and friends as one of the marketing channels. Farmers sold their animals to relatives and friends when they get extra premium. Village collectors were one of the major channels for about 65 per cent of the respondents. According to Solomon (2006), these types of traders participate in trading business at the time of high margins (New Year, and religious festivals). Lack of markets close to their village might be the main reason for this. These village collectors inturn sold these animals to nearby slaughter house or most of the times they themselves own a slaughter house. Around 50 per cent of the respondents sold their animals through market. These were unorganized markets and many times middlemen get maximum benefit than the producers. Region wise also relatives and friends were the major marketing channel followed by village collectors and local markets.
Reasons to sell through particular marketing channels: Farmers were asked to specify the reasons for selling their animals through a particular channel. It could be noticed from the table 2 that to sell through village collectors maximum respondents (79.4\%) reported easy and fast followed by collection from house $(53.8 \%)$, advance payment $(27 \%)$ and availability of credit $(10.2 \%)$ as main reasons to sell their animals.

Respondents from semi-arid zone (27.2\%) and arid zone $(6.6 \%)$ reported availability of credit as one of the reasons. However, none from coastal zone respondents quoted this reason. The role of brokers in marketing small ruminants in the area has two views; one group describes them favorably as they facilitate transaction between buyers and sellers while others see them as problems in marketing as they are the ones who mainly decide on the price. In agreement with this report, the role of brokers was also described by other reports (Endeshaw 2007 and Tsedeke 2007).

Remunerative price that the farmers get for their animals was given top reason for selling animals through market by majority of the respondents $(80 \%)$. For selling their animals to relatives and friends, respondents offered several reasons. Advance payment as a reason was reported by 33.3 percent of respondents 
Table-3. Pricing system of small ruminant animals.

\begin{tabular}{|c|c|c|c|c|c|c|c|c|}
\hline \multirow{2}{*}{$\begin{array}{l}\text { Opinion on price differentiation and reliability of } \\
\text { village collector }\end{array}$} & \multicolumn{2}{|c|}{ Semi-arid Zone } & \multicolumn{2}{|c|}{ Arid Zone } & \multicolumn{2}{|c|}{ Coastal Zone } & \multirow{2}{*}{$\begin{array}{l}\text { Pooled } \\
\text { Yes }\end{array}$} & \multirow{2}{*}{ No } \\
\hline & Yes & No & Yes & No & Yes & No & & \\
\hline Price difference between market and village collector & 75 & 25 & 40 & 30 & 85 & 15 & 77 & 23 \\
\hline Reliability of village collector in price determination & 40 & 60 & 35 & 65 & 45 & 55 & 40 & 60 \\
\hline Village collectors & 100 & 0 & 100 & 0 & 100 & 0 & 100 & 0 \\
\hline Local Market & 80 & 20 & 83.3 & 16.6 & 75 & 25 & 80 & 20 \\
\hline Relatives and friends & 88.8 & 11.1 & 84.2 & 15.7 & 82.3 & 17.6 & 85 & 15 \\
\hline Was the price satisfactory? & 25 & 75 & 33.3 & 66.6 & 36.3 & 63.6 & 30.7 & 69.2 \\
\hline
\end{tabular}

followed by easy and fast $(29.6 \%)$, remunerative price $(25.9 \%)$, personal dealing $(18.5 \%)$, correct price determination $(16.6 \%)$, collection from house $(16.6 \%)$ and availability of credit 7.4 percent.

Market plan: Farmers were asked whether they have any marketing plan, if yes to what extent they plan. Table-2 shows that majority of the respondents (53.3\%) did not have any market plan. The possible reason of this may that farmers are not aware about the market plan or and they are not business oriented. Majority of the farmers in India, keeping small ruminants for their livelihood and meet out the routine expenditure.

Price estimation: It is also evident from the Table- 2 that estimation of price of the animals while marketing was mainly based on the body condition as reported by majority of the respondents $(46.6 \%)$. This was followed by both body condition and market demand (38.3\%) and market demand alone (15\%). Body condition includes healthiness of the animal, body configuration, average weight according to age, etc. This was in agreement with Ogola et al 2010 who found that the price was higher than that of indigenous goats, but lower than that of the exotic parent stock. The variation in the sales value was an indication of poor record keeping, lack of an organized market, or market organization with no standards. More male animals were sold compared to females, and farmers incurred no cost during sale. About $86.6 \%$ of the goats sold were less than one year old, implying a shortage of the dairy goats in the market or a quick need for cash and also with Alam (2000) who found that landless and resource constrained farmers sold their goats at an early age, and with low market weight as they largely depended on income from them

Difference in price of animals and reliability of village collectors: Table- 3 shows that there was difference between price of animals in market and price offered by village collectors. About 77 per cent respondents reported that there was difference. Regionwise also similar type of responses were found.
This might be because of fewer prices offered by village collectors when they come to villages for collecting animals. It is also evident from the Table- 3 that majority of the respondents $(60 \%)$ reported that the village collectors were not reliable in price determination. Few respondents opined that in some instances village collectors gave false information about actual current market price and also they undervalue the animals as they are expert in judging the body weight of animals. The availability of small ruminants for religious celebrations is absolutely necessary; therefore the demand and price for sheep and goats towards the Idul Adha celebration increases dramatically (Djajanegara and Chaniago 1988). According to Panin and Mahabile (1997), Moslems' preference for sheep meat is a crucial factor for rearing sheep. Reasons for the preference of sheep could be related to a preference for fat meat (Thys and Wilson 1996). In Pakistan, Rodriguez et al (1995) also found that farmers felt that they were not in a position to bargain efficiently, because of the frequent need of selling small ruminants for urgent cash requirements. Farmers also complained that there was no marketing information available to them. The only information they receive is via the village collectors. For poultry products the government releases information on product prices on a regular basis. Such information should also be made available to small ruminant keepers. Maybe in the future, modern communication technologies could be helpful in this. Marketing practices would depend on the feeding mode. It would be more interesting for breeders, to sell live animals in the case of kids reared at pasture whereas for the others in the form of entire carcasses if a grading system is used (Alexandre et al 2009).

Declining a selling price and ending up in not selling: Farmers were asked if they have ever declined the offer for their animals citing less value and ended up in not selling. They were asked to respond to this question only against those channels which they used. It can be observed from Table- 3 that cent percent of the farmers who sold their animals to 
village collectors ended up in not selling at least once. About 80 per cent respondents who used market to sell their animals also faced such situations at least once. Likewise about $85 \%$ of the respondents faced same thing with relatives and friends.

Marketing of injured animals: It can be observed from the Table- 3 that about 65 per cent respondents sold injured animals at least once. Among those, $69.2 \%$ respondents felt that the price for the injured animals was not satisfactory.

\section{Conclusions}

The study clearly shown;

- Majority of the respondents were illiterate and marginal farmers. The study also revealed that average flock size was 9.6 and average income from small ruminant farming was INR 6671.67. Small ruminant farmers were getting handful income from their animals which act as source of income during economic crisis and also they invest in these smallstocks as current stocks.

- Majority of farmers (85\%) sold their animals when they needed cash for home consumption followed by to pay off loan, whereas $25 \%$ respondents sold their animals to pay their school children fees.

- $\quad$ Relatives and friends were the major marketing channel followed by village collector and local market. Majority of the farmers did not have any market plan for their animals.

- $\quad$ Body conditions and market demand the main based for price estimation in the areas.

\section{Acknowledgements}

Authors are thankful to the ICAR, Director and Joint Director (Academic) of Indian Veterinary Research Institute for providing necessary facilities and financial support for conducting this study. Authors are also thankful of small ruminant owners of different agroclimatic zones of Karnataka state participation in the study.

\section{Conflict of interest}

Author declare that they have no conflict of interest.

\section{References}

1. Abule E (1998) Role and decision making power of women in livestock production around Adami Tulu. ESAP (Ethiopian Society of Animal Production). Proceedings of 6th annual conference of the ESAP held in Addis Ababa, Ethiopia, August 14-
15 May 1998. pp 95-102.

2. Alam M R (2000) Goat rearing in the smallholder farming systems in Bangladesh. In: Proceedings of the Seventh International Conference on Goats, 15-21 May, 2000, Tours, France, pp. 329-330.

3. Alexandre G, Arquet R, Gravillon G, Weisbecker JL and Mandonnet N (2009) Carcass characteristics of Creole goat of Guadeloupe (FWI) as a function of pre-weaning performances and post-weaning management. Livestock Research for Rural Development (21) http://www.lrrd.org/lrrd21/4/cont 2104.htm.

4. BAIF Publication (2008)http://sapplpp.org/ thematicfocus/small-ruminants.

5. Djajanegara A and Chaniago T D (1988) Goat meat production in Indonesia. In: Devendra C. (Ed), Goat Meat Production in Asia. Proceedings of a workshop. Tando Jam, Pakistan, pp. 135-139.

6. Endeshaw A(2007) Assessment on production system and marketing of goats at Dale district (Sidama Zone). MSc Thesis. Hawassa University, Awassa, Ethiopia. FAO (Food and Agricultural Organizations of the United States). 2009. FAOSTAT data http://faostat. fao.org/faostat/collections?subset=agricuture.

7. Getahun L (2008) Productive and Economic performance of Small Ruminant production in production system of the Highlands of Ethiopia. Ph.D.dissertation. University of Hohenheim, Stuttgart-Hoheinheim, Germany.

8. Misra A K (2005) Contingency planning for feeding and management of livestock during drought. In: K D Sharma and K S Ramasastri (Editors) Drought Management. Allied Publishers Pvt. Ltd., New Delhi.

9. Ogola T D, Nguyo W K and Kosgey I S (2010) Dairy goat production practices in Kenya: Implications for a breeding programme. Livestock Research for Rural Development (22)1: http://www.lrrd.org/lrrd22/1/ cont2201.htm.

10. Panin A and Mahabile M, (1997) Profitability and household income contribution of small ruminants to small-scale farmers in Botswana. Small Rumin. Res. 25, 9-15.

11. Pankaj Lavania and Singh P K (2008) Goat marketing practices in southern Rajasthan. Indian Journal of small ruminants, 14(1): 99-102.

12. Pasha S M (2000)Economy and ecological dimensions of livestock economy. Commonwealth publishers, New Delhi.

13. Pollot G and Wilson RT (2009) Sheep and Goats for diverse products and profits (FAO Rome) In: FAO Diversification Booklet (FAO), no. 9 / FAO, Rome (Italy). Rural Infrastructure and Agro-Industries Div, 2009, 42.

14. Porwal K, Karim S A, Sisodia S L and Singh V K (2006) Socio economic Survey of sheep farmers in Western Rajasthan, Indian Journal of Small Ruminants, 12(1): 74-81.

15. Rangnekar D V (2006) Livestock in the livelihoods 
of the underprivileged communities in India: A review. ILRI (International Livestock Research Institute), Nairobi, Kenya. 72 pp.

16. Rodriguez A, Ali I, Afzal M, Shah N A, Mustafa U (1995) Price expectations of sheep and goats by producers and intermediaries in Quetta market, Pakistan. Agric. Econ. 12,79-90.

17. Tsedeke K (2007) Production and marketing of sheep and goats in Alaba, SNNPR. M.Sc Thesis. Hawassa University.Hawassa, Ethiopia.

18. Solomon G G (2006) Genetic diversity and Conservation priorities for Ethiopian sheep
Proceedings of a workshop on Sheep Breeding Strategies for Ethiopia held at ILRI, Addis Ababa, Ethiopia on 21 November 2006. ILRI (International Livestock Research Institute), Nairobi, Kenya.

19. Thys E and Wilson R T (1996) Age and sex composition of small ruminants at Nouakchott markets, Mauritania. Small. Rumin. Res. 20, 281-284.

20. Workneh A, Rischkowsky B, King J M and Bruns E (2003) Crossbreds did not create more net benefits than indigenous goats in Ethiopian smallholdings. Agric. Sys. 76, 1137-1156. 